\title{
Subterrânea: por um estado de emergência efetivo
}

\author{
Flávia Cera*
}

\begin{abstract}
Resumo:
Nesse texto iremos trabalhar a categoria de "subterrâneo" de Hélio Oiticica, e tentar perceber de que maneira ela se associa com uma proposta política de sua obra. Essa categoria será entendida como um estado de emergência, como um estado de latência com o qual Oiticica tenta escrever um conceito de povo. Nesse sentido, não há uma separação de classes, nem minorias ou maiorias, mas uma coletividade desejante cujos corpos miram a felicidade, ou seja, um estado de emergência efetivo.
\end{abstract}

\section{Palavras-chave:}

Subterrâneo, Hélio Oiticica, Parangolé.

A proposta de um texto sobre o subterrâneo remete a uma escavação, a uma arqueologia, como que se estivesse mais no fundo o que gostaríamos de saber. Contudo nesse texto o subterrâneo se apresentará de maneira diferente; aqui ele está na superfície, nos corpos, e está de acordo com a proposição de Valéry quando afirma que "o mais profundo é a pele". A proposta consiste em ler algumas obras de Hélio Oiticica não o compreendendo apenas como um artista plástico, mas sim um teórico do presente que expõe sua obra como uma dança de conceitos, uma vez que o samba e o rock fizeram parte do universo artístico e teórico criados por ele. A Mangueira, escola de samba pela qual desfilava, é uma das protagonistas de todo seu período de produção, desde os Parangolés até as instalações. Alain Badiou, no seu Pequeno Manual de Inestética, diz que a dança é uma metáfora do pensamento. A dança, segundo o filósofo, se apresenta como pura exposição dos corpos, e mostra apenas que o corpo é capaz de arte. Ou seja, a dança é uma metáfora do pensamento porque abre o corpo à possibilidade, abre-o a um novo uso. A dança se apresenta como uma "mostração permanente relativa ao que está acontecendo" - diz Badiou (2002, p. 92) -, e é na sua efemeridade, "já que desaparece assim que ocorre", que a dança detém a eternidade conservada no seu desaparecimento: presa na

\footnotetext{
* Doutoranda em Literatura na Universidade Federal de Santa Catarina.
} 
iminência, tal qual o subterrâneo proposto por Oiticica, ela é sempre um acontecimento de um "tempo antes do tempo que vai haver". Um tempo no interior do tempo. Vejamos, então, de que forma Oiticica viabiliza as experiências subterrâneas onde tenta articular um povo, ${ }^{1}$ uma coletividade, que não é outra coisa, senão um "exercício experimental da liberdade", como queria Mário Pedrosa, que tem em vista à felicidade.

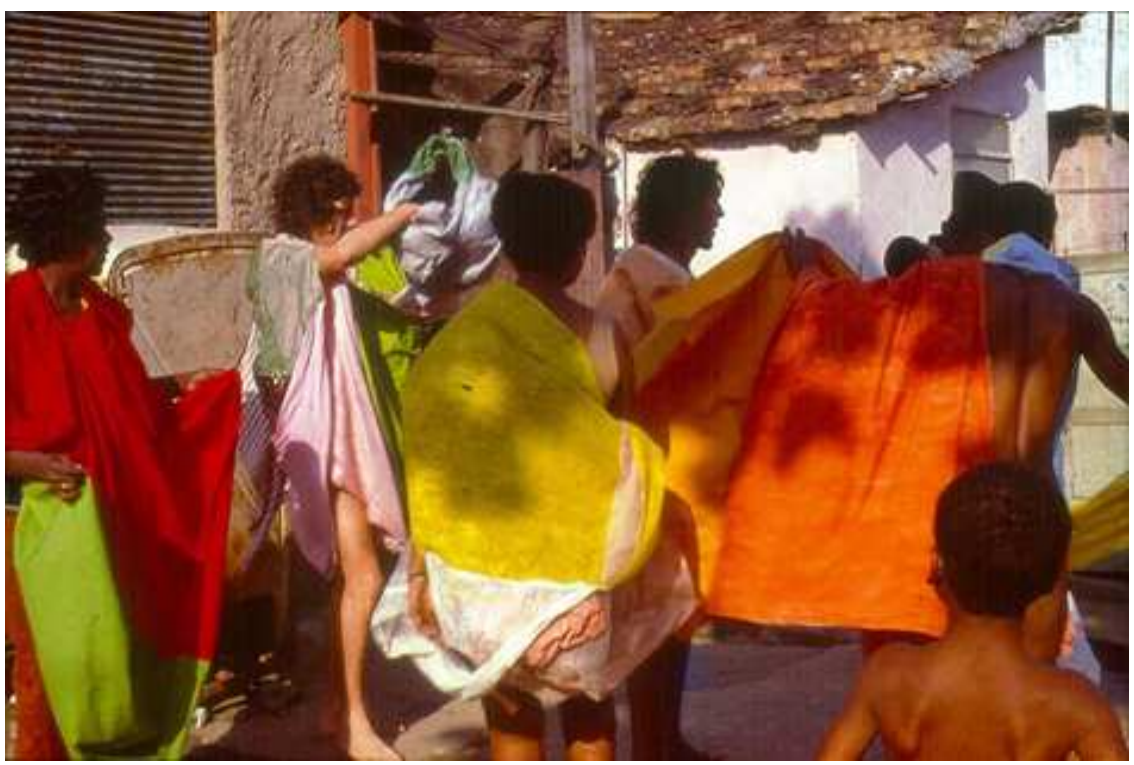

Figura 1 - Parangolés no Morro da Mangueira

Em 1966, na tentativa de elaboração de uma nova vanguarda, Oiticica escreve o Esquema Geral da Nova Objetividade. ${ }^{2}$ Com esse manifesto o artista reivindica e reelabora a antropofagia oswaldiana denominando-a Super-antropofagia:

A antropofagia seria a defesa que possuímos contra tal domínio exterior, e a principal arma criativa dessa vontade construtiva, o que não impediu de todo uma espécie de colonialismo cultural, que de modo objetivo queremos hoje abolir, absorvendo-o definitivamente numa Super-antropofagia (OITICICA, 1966).

Para alcançar tal objetivo, Oiticica (1966) fixa seis pilares para a Nova Objetividade: 1) "vontade construtiva geral"; 2) "tendência para o objeto ao ser

\footnotetext{
${ }^{1}$ Essa tentativa de articular um povo é apreendida da proposta de Giorgio Agamben. Quando o filósofo evidencia a existência de dois povos (Povo e povo, grosso modo, incluídos e excluídos) mostra que há uma relação de dominação de um sobre o outro (as relações trabalhadas exaustivamente em Homo Sacer sobre a exclusão-inclusiva) e que essa separação nasce de uma fratura biopolítica. Toda tentativa de unificação do povo, ou seja, de obturar esse espaço entre Povo e povo, resta violenta, ela sempre se dá pela eliminação de um povo. A proposta de povo que defendemos aqui com Hélio Oiticica não diz respeito à unificação de um povo, ao contrário, é fundamentado em uma singularidade radical que se defende esse conceito. Trata-se de uma sociedade sem classes, sem exclusão ou inclusão: anarquista, como veremos.

2 Esquema Geral da Nova Objetividade foi escrito no fim de 1966 por Hélio Oiticica e rendeu uma exposição em abril de 1967 no MAM/RJ.
} 
negado e superado o quadro de cavalete"; 3) "participação do espectador (corporal, tátil, visual, semântica, etc)"; 4) "abordagem e tomada de posição em relação a problemas políticos, sociais e éticos"; 5) "tendência para proposições coletivas e conseqüente abolição dos "ismos" característicos da primeira metade do século na arte hoje"; 6) "ressurgimento e novas formulações do conceito de anti-arte". A Nova Objetividade é, portanto, caracterizada como um estado da arte que pretendia a criação de uma situação, e não como uma posição estética que pressuporia, na concepção de Oiticica, uma unidade de pensamento. Ao contrário, o que define a Nova Objetividade é "a falta de unidade de pensamento", heterogeneidade que só poderia ser encontrada, dizia Oiticica, no movimento Dadá. "A 'Nova Objetividade' sendo um estado, não é pois um movimento dogmático, esteticista (como por exemplo o foi o cubismo, e também outros ismos constituídos como uma 'unidade de pensamento')". ${ }^{3}$ Começava ali a proposta de criação de uma multiplicidade.

Entretanto, a intenção da Nova Objetividade é claramente de ruptura. Oiticica tenta ainda montar um movimento, uma vanguarda. Propõe um procedimento centrado no objeto, na objetividade, a ponto de Mario Schenberg poder denominar o movimento de realista. ${ }^{4}$ Não raro as inserções das dimensões sociais na arte são interpretadas como realistas, como se houvesse ali uma boa ação do artista que o deixaria mais humano e popular aproximando o que se diz "cultura erudita" da massa analfabeta. Como se essa massa estivesse ali, plenamente à vista, mas ainda não representada ou interpretada. O artista então procederia como um retratista da realidade sistematizado dentro do circuito artístico para que se possa dar a ver. Que essa visão da crítica esteja mais do que equivocada porque, evidentemente, estabelece uma posição hierárquica de acesso e representação, não é novidade. Existe no trabalho de Oiticica uma carga de realismo, com todas as conotações do termo, só que em outro contexto e, mais ainda, uma carga do Real lacaniano, um encontro com o Real (a favela, o "bandido", a morte), e não menos, um desejo de furar esse Real que é irrepresentável. O fim do quadro tão anunciado por Oiticica toma corpo aí, quando a realidade é inabarcável em uma forma, quando a realidade só se apresenta como força, quando a vida se apresenta, apenas, como

\footnotetext{
3 As citações dos textos de Hélio Oiticica serão indicadas apenas com as datas porque os documentos consultados estão no seu arquivo. Alguns textos, como "A Nova Objetividade", já foram publicados em livro. Nas referências estão listados todos os documentos consultados no arquivo que tem boa parte disponibilizada on-line no Programa Hélio Oiticica do Itaú Cultural.

${ }^{4}$ As discussões sobre o realismo nesse período vêm desde $1965 \mathrm{com}$ as exposições Proposta 65 e Opinião 65. Celso Favaretto (2000), no capítulo sobre a Nova Objetividade, apresenta essas discussões.
} 
intensidade. É aí que se coloca uma grande pergunta: como interferir nesse Real, que insiste, persiste?

Três anos mais tarde, entre os meses de setembro e outubro de 1969, na Inglaterra, Oiticica reelabora o "processo" das suas proposições. Desse encontro com o Real nasce um conceito: subterrâneo. Dois textos surgem com essa proposta em forma de manifesto: Subterrânia [sic], transcrito abaixo, e Subterrânia 2 [sic].

Sou eu é você e América Latina Sul Sub embaixo da terra longe do falatório dentro de você condição única de criação: do mundo para o Brasil: no Brasil $\rightarrow$ no submundo algo nasce e germina culmina ou é fulminado como fênix nasce da própria cinza (cafono) $\rightarrow$ subterra: romântico cafono clássico ortodoxo folk-pop consciente místico lírico (+neo + sub tudo) tropicália é o grito do Brasil: não quero usar "underground" (é difícil demais pro brasileiro) mas subterrânia [sic] é a glorificação do sub - atividade - homem mundo - manifestação: não como detrimento ou glori-condição $\rightarrow$ sim: como consciência para vencer a super - paranóia - repressão - impotência - negligência do viver: marcha fúnebre $\rightarrow$ enterro e grito consciência - crítica - creativa [sic] - ativa $\rightarrow$ necessidade - do disfarce - do surrealismo-farsa - do sub-sub - da redundância $\rightarrow$ longe dos olhos $\rightarrow$ perto do coração: ou da côr da ação: debaixo da terra como rato de si mesmo: RATO é o que somos símbolo flama enterremo-nos vivos desapareçamos sejamos o não do não o nó omitido a não-omissão $\rightarrow$ creomissão $\rightarrow$ missa missão eu sou o astronauta o Brasil é a lua cuja poeira mostrar-se-á ao mundo sublixo. (OITICICA, 1969a)

Oiticica percebe aí que a condição única de criação é subterrânea. Ele lista uma série de necessidades para que se possa criar um ambiente criativo: o surrealismo, a redundância, o grito. Ou seja, quebrar a lógica, sair do certo e errado, do oficial, do "bom gosto", ser cafona: abrir-se para o mundo, para o sub-mundo. Fora a evidência do golpe militar de 1964, que pressupunha que toda reação fosse subterrânea, ou seja, clandestina, Oiticica também está dizendo que o subterrâneo é uma zona de não-saber, obscura, portanto, e arisca às tentativas de apropriação, ou ainda, à tentativa de torná-la clara, explícita, iluminada. Diz também que ela é feita de poeira, algo frágil, efêmero e menor, mas que, entretanto, aventa uma possibilidade de restituição já que nela encontramos as marcas produzidas pela história. Além disso, temos o fato de Oiticica se aproximar do samba e do Morro da Mangueira em uma década que priorizou o afastamento e o isolamento. Contra a imunidade estatal, Oiticica respondia com o contágio do mundo, do sub-mundo, dessa poeira que se tentava jogar para debaixo do tapete. 
Em novembro de 1969, com a experiência que chama de "Capas construídas no corpo", Oiticica assume que seus trabalhos são subterrâneos. As capas são os Parangolés, elaborados ainda em 1964, mas que estavam passando por um processo de metamorfose. Oiticica vislumbrava, mais do que "objetos-capa", um "ambiente-prática" (1969b). Não é difícil reconhecer uma sorte de projeto utópico em Oiticica. É visível que suas ambições extravasavam o circuito artístico e se dirigiam para o mundo, como no caso da sua instalação MundoAbrigo, ${ }^{5}$ pensada a partir das idéias de seu avô anarquista José Oiticica, ou ainda em seus Ninhos ou nos penetráveis Éden ${ }^{6}$ e Barracão, ${ }^{7}$ todos eles inspirados nos espaços da favela, tendo como princípio a não-divisão dos ambientes. De modo que toda concepção antropofágica de devoração, ou de criação de um marco zero, de uma origem nacional cai por terra se acompanhamos atentamente o desenrolar da sua produção. O anárquico (anarché, ou seja, sem fundamento) coloca-se aqui como a negação da origem. Oiticica traz à baila o tema do subdesenvolvimento trabalhado na mesma época, por exemplo, por Antonio Candido em Literatura e Subdesenvolvimento (1970); ele segue, entretanto, com uma proposta um pouco diferente da lançada pelo crítico, a saber, a superação, o supra-regionalismo: ao invés de uma prática de elevação da vida, mirando sempre a cabeça, prática contra a qual Georges

\footnotetext{
${ }^{5}$ Em Mundo-Abrigo encontramos uma proposta de comunidade como uma experiência de estar junto uns com os outros no abandono de algo comum, de uma propriedade, para dar vazão à liberdade. "Mundo-abrigo implica num tipo de experiência em vários níveis e a relação-conduta de cada indivíduo com ela tem importância fundamental. Para chegar ao MUNDO-ABRIGO não é só preciso abandonar a vontade mesquinha de possuir fetichistamente objetos deste mesmo desejo fetichista (isso é passo-implícito já não mais problemas ou dilema moral como antes) de propriedade (como se fossem substitutivos para uma 'solução' no MUNDO existencialmente vivido como produção versus morte): é mais e mais do que isso é sentir-se livre (sem 'condições ideais') para assumir o experimental no comportamento (relações com o MUNDO)" (OITICICA, 1973a). Oiticica propõe com o Mundo-abrigo a negação das classes, das classificações, o abandono do desejo de propriedade e a não submissão da liberdade aos determinismos, em suma, uma ética.

${ }^{6}$ Éden agrega uma série de proposições que Oiticica elabora depois da Tropicália; na sua concepção novos conceitos aparecem, tais como o Supra-sensorial e o Crelazer, além da dimensão in progress ou inacabada que na Tropicália ainda não aparecia: "Toda concepção de Éden se inicia nisso: na transformação de uma síntese imagética, a Tropicália, passando pela formulação do Supra-sensorial, até a idéia de Crelazer, que teve sua primeira conflagração com a Cama-Bólide e com os bólideáreas, feitos desde 1967 [...]. o Éden não está submisso entretanto a uma forma acabada, mas à proposição permanente do Crelazer" (1969c). Éden, entretanto, mantém a sua proposta de lugar do pecado original na proposição de Hélio Oiticica quando ele o define, de maneira bem próxima da antiga doutrina teológica, como: "'um campus experimental, uma espécie de taba, onde todas as experiências humanas são permitidas - humano enquanto possibilidade da espécie humana" (OITICICA, 1969d), ou ainda como uma "equação. tela de possibilidades. screen of possibilities. perdida inocência no jardim do Éden" (OITICICA, 1973), na formulação de Waly Salomão apropriada pelo artista.

7 Barracão é citado no projeto "Subterrânia" (OITICICA, 1970a) como o "lugar-lazer necessário". Oiticica explica da seguinte maneira o Barracão: "o uso do nome que vem da moradia na FAVELA é o que eu queria como 'algo que não nasce da casa estruturada nos modelos conhecidos: BARRACÃO não seria imitar a estrutura-espaço do BARRACÃO no morro' isso seria burrice por não possuirmos o tipo de experiência igual a do morador do morro, mas semelhante a dele: o que me atraia então era a não-divisão do BARRACÃo na formalidade da casa". Barracão era o lugar que reunia o separado, era a não divisão que procurava uma "ligação orgânica entre as diversas partes funcionais no espaço interno-externo do mesmo" (OITICICA, 1973a).
} 
Bataille chama atenção nos seus verbetes Baixo Materialismo e Dedão do Pé, Oiticica propõe o subterrâneo, a dimensão obscura de um não-saber. Uma intervenção na ordem das coisas que abre para o fora, ou como queria Oiticica (1969b): "prática-grito latino-americana moldada criada fora, no mundo para $\rightarrow$ ". Ou ainda, uma prática decorrente do corpo, uma prática comum que, como veremos, se tornará uma prática política exercida na rua.



Figura 2 - Planta do Éden

O artista concentra, então, seus esforços na construção de uma coletividade ou ainda, tenta reformular uma condição de povo que estava sendo domesticada e anestesiada pela Ditadura. ${ }^{8}$ Entretanto, Oiticica não reivindica uma politização da vida, ou uma politização do povo. Não se trata absolutamente de uma revolução. Essa seria para ele uma outra maneira de disciplinar os corpos. Como

\footnotetext{
${ }^{8}$ A leitura do movimento underground estabelecida por Heloisa Buarque de Hollanda em Impressões de Viagem, embora seja mais ampla que a noção de subterrâneo proposta por Oiticica, vincula-se à idéia de minoria: "A realidade dos grandes centros urbanos é valorizada agora em seus aspectos 'subterrâneos'; marginal do Harlem, eletricidade e LSD, Rolling Stones e Hell's Angels. A identificação não é mais imediatamente com o 'povo' ou o 'proletariado revolucionário', mas com as minorias: negros, homossexuais, freaks, marginal de morro, pivete, Madame Satã, cultos afrobrasileiros e escola de samba" (HOLLANDA, 2004, p. 75). Nesse sentido, vamos na contramão do sentido empregado pela autora, atribuindo à instância de subterrâneo a dimensão de povo justamente porque o artista não visava a separação, mas uma coletividade. Talvez esteja aí uma explicação para a recusa de Hélio Oiticica do termo underground.
} 
buscava uma evolução, não havia lamentos de poucos leitores, ou de poucos espectadores, ou de poucos participadores. Ele também não pretendia uma alfabetização do povo, nem a glorificação do subdesenvolvimento - embora afirmasse que sim. Oiticica tampouco manteve uma relação de exotismo com a favela. Não era o caso de apresentar ou de impor ao mundo, ao centro, uma parte esquecida da população - não se tratava de um Cosmopolitismo do Pobre nem de incluir os Pobres na Literatura Brasileira. Ao assumir uma postura marginal, Oiticica transitava, como ele mesmo diz, sem lugar no mundo, sem almejar uma classe. De modo que, podemos dizer, ele não pretendia uma inscrição da vida fora da norma, o que pressuporia uma possibilidade de reinscrição, mas uma suspensão dessa norma. Uma suspensão do dentro-fora. Mas Oiticica sabia que para alcançar essa meta, teria que dar pequenos passos: "incorporo a revolta" - escreve em um de seus Parangolés. Não era o caso de criar uma consciência de classe, isso já não fazia mais sentido para ele, tratavase sim de inscrever essa revolta no corpo e dar corpo a essa revolta.

Com os Parangolés, Oiticica insere a dimensão do outro na arte, que ele chamará formalmente de participador. Insere, assim, a dimensão do desejo e, conseqüentemente, da ética: "a busca geral da felicidade é, sem dúvida, o fim da arte, o seu ponto crucial" (OITICICA, 1967). Ao incluir o outro, Oiticica mostra mais uma vez que sua proposta não está tão marcada pela ação, ou pela revolução, como preconizam alguns críticos, mas sim pela paixão. Ao sustentar o outro nas suas criações ele entende que os corpos podem ser afetados. É claro que existe a importância do ato, da ação em sua obra, mas o que é pertinente ressaltar aqui é que, pelo menos conceitualmente, Oiticica sugeria um estado de latência, de iminência, de insurreição. Ou seja, um ato que conservaria em si possibilidades. Era a proposta de uma criação produzida pelo contato, pelo afeto. A capa que acolhe e abandona, veste e despe, articula a entrada do corpo na arte, a entrada de uma vida abandonada, uma vida que vem de baixo. Criada fora e não para fora; Oiticica parte do mundo, do baixo mundo: da América Latina para o mundo. 


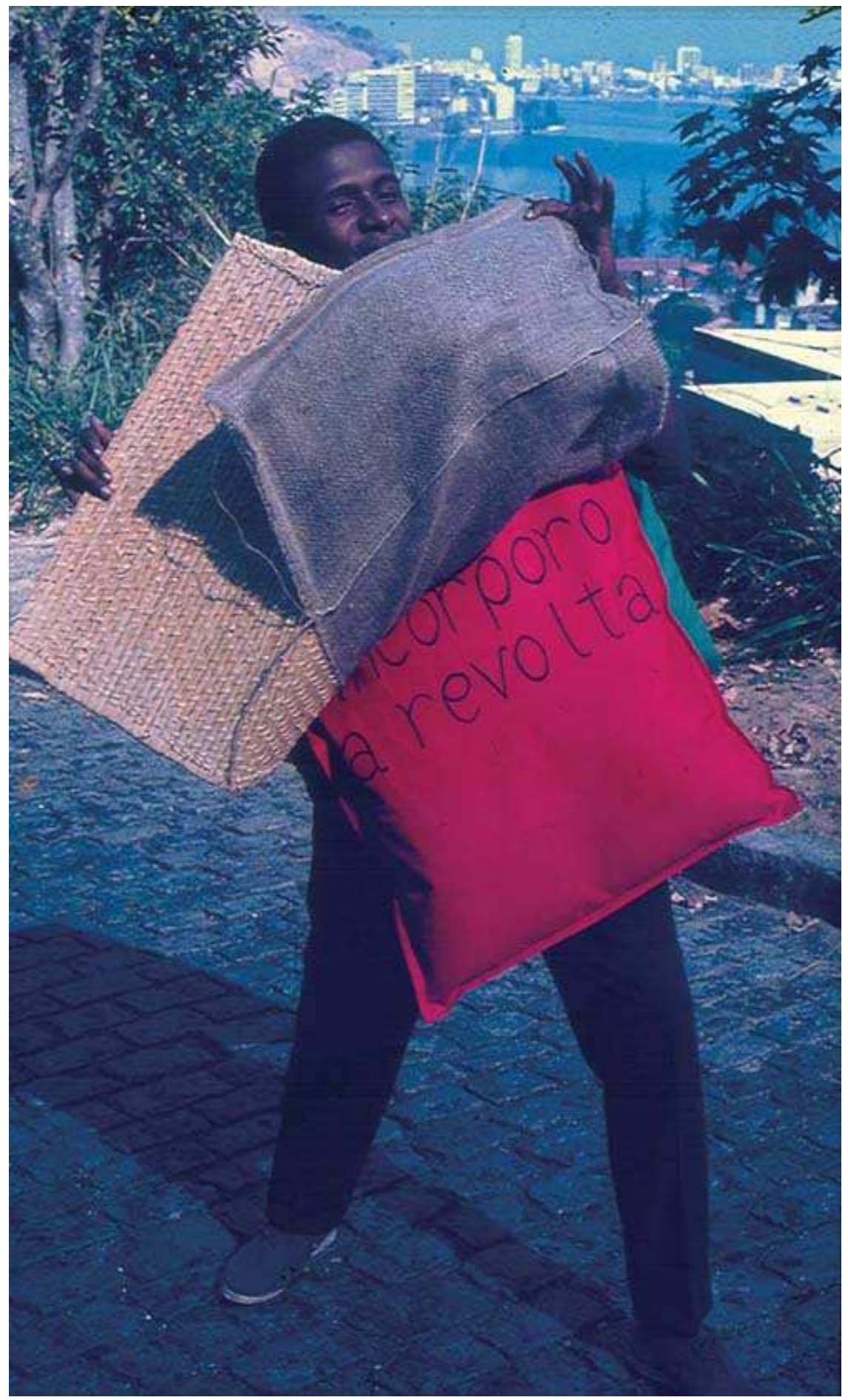

Figura 3 - Parangolé "Eu incorporo a revolta"

No entanto, o caráter sub do povo não implica aqui uma interioridade ou ocultamento, ao contrário, é a exterioridade que garante esta condição, é enquanto corpo nu, enquanto pura exposição que a vida é subterrânea: o que está em baixo, o que "fede", o que amedronta, e que pode, a qualquer momento, emergir, não para o confronto, mas para um transbordamento, 
alguma coisa de incontrolável: um estado de emergência do povo. ${ }^{9}$ A emergência não pode ser lida descolada de um de seus significados, a contingência. Optar por uma coletividade subterrânea implica admitir a possibilidade do acontecimento. Implica admitir a dimensão do acaso, da irrupção repentina. Como pura receptividade e uma espera, Oiticica formula uma nova forma de esperança fundamentada na contingência. Ou seja, na possibilidade de as coisas não serem do jeito que são. Com a possibilidade de, a qualquer instante, se exercer essa prática-grito para "interferir no imponderável". Essa seria, portanto, uma forma de terrorismo, mas de um terrorismo às avessas porque não tenta uma tomada de poder. Porque não tenta infringir o medo como política, mas a suspeita de que nem tudo está como poderia estar. Enquanto revolta, enquanto compreensão de que todo instante pode ser um instante de perigo, a prática subterrânea tenta suspender o tempo. De modo que, poderíamos dizer, a prática subterrânea tem como uma das suas prerrogativas criar alternativas para sair do tempo cronológico. Proposta que encontramos na definição do próprio artista do que seria um momento criativo: "vem quando do mundo nada mais se ouve, há a saturação do mundo das suas coisas, de sua relatividade. Chega então o 'momento sublime'. O tempo já não conta como cronologia; as idéias encontram-se com o seu tempo. São sublimes e se realizam" (OITICICA, 1961).

A prática subterrânea propõe um corte no contínuo cronológico com a inserção do corpo: "a minha atividade atual, no seu todo, quero chamar de subterrânea: não será exposta, mas feita; seu lugar no tempo é aberto" (OITICICA, 1970a). A dança é aí fundamental para essa concepção. É através dela que Oiticica vislumbrará, alguns anos antes, um projeto coletivo e comum.

A improvisação reina aqui no lugar da coreografia organizada; em verdade, quanto mais livre a improvisação, melhor; há como que uma imersão no ritmo, uma identificação vital completa do gesto, do ato com o ritmo, uma fluência onde o intelecto permanece como que obscurecido por uma força mítica interna individual e coletiva (em verdade não se pode aí estabelecer a separação) (OITICICA, 1965).

Esse intelecto obscurecido onde os corpos habitam o espaço é o que podemos dizer comum entre os seres, afinal, como o próprio Oiticica diz, não se pode estabelecer uma separação. O comum seria esse estágio pré-individual e

\footnotetext{
${ }^{9}$ Nesse sentido, poderíamos pensar em uma leitura subterrânea também para $A$ hora da estrela e na dedicatória que abre o livro, onde Clarice Lispector (1999, p. 10) escreve: "Esta história acontece em estado de emergência e de calamidade pública", sem esquecer que uma das definições, entre tantas, que Rodrigo S.M dá a Macabéa é: "ela era subterrânea".
} 
impessoal do corpo. Ou ainda, zoé, termo também utilizado por Aristóteles para designar o pensamento. É nesse estágio de quase êxtase da dança que Oiticica cria um conceito de povo para o qual vislumbra uma nova forma de comunidade: "sonho não mais de comunidade piritamizada, castificada mas comunidade do corpo em dança" (OITICICA, 1973b). Daí seu projeto comum, não de comunhão, mas de uma forma de contato, de afeto que será perseguido através das imagens. Esse projeto é explicitado de maneira mais contundente em Bodywise, um documento em que escreve sobre o uso das capas, já na década de 1970 e já com a absorção das Galáxias de Haroldo de Campos. Nele, Oiticica (1973c) reivindica a dimensão da fantasia, do fantasma: "a roupa se aproxima da fantasia q também (em ambos os casos) não se querem reduzir a 'mediadoras' como sejam os objetos ritualísticos a gratuidade originária em ambas as livra não só do role (função) como dos compromissos com mediações ritualísticas livrando-as ao jogo livre do clímax-corpo com as possibilidades abertas ao uso delas". A fantasia, o fantasma, a imagem são meios puros. E se há na dança, como explica Hélio, ou como explica Giorgio Agamben (2004), a dimensão do fantasma, há também a dimensão da memória.

Uma das ambições de Oiticica quando escreve "Meu trabalho é subterrâneo" era criar uma "face-lugar" (OITICICA, 1970b), um rosto do qual não se poderia esquecer. E aqui não podemos esquecer Cara de Cavalo, amigo de Oiticica, um "bandido" morto pela polícia. Oiticica vai até esse "Homo Sacer" para dizer que ali há vida. Uma vida que insiste. Dessa insistência em se dizer vida, Oiticica diz que sua cara não é nova (que é preciso ter memória), é a mesma cara, de novo, um espelhamento - uma sobrevivência: "ele é e existe" - e, "não é triste/como artrite que nos acomete/no pântano/ou no apartamento/de cimento/o cimento que cobre o ato/o tato/o crime/que já deixa de ser". Da imagem de Cara de Cavalo temos "apenas um tremor/imponderável", e "não o horror" (OITICICA, 1968) porque diante dela temos a certeza de que somos nós que estamos ali também, a mesma certeza que teve Clarice Lispector quando afirmou que o décimo terceiro tiro disparado contra o bandido Mineirinho a matava. São destes fantasmas que não podemos esquecer. Daí as capas não cobrirem o rosto, ${ }^{10}$ daí a ênfase na cara de Cara de Cavalo. Outro exemplo: em 1979, Oiticica elabora um Parangolé em homenagem aos seus amigos assassinados. Chama-se Ronda da Morte, sobre o qual ele escreve:

\footnotetext{
${ }^{10} \mathrm{O}$ rosto para uma série de autores, entre eles, Emmanuel Lévinas, Gilles Deleuze, Félix Guattari e Giorgio Agamben, é a instância mais política do homem por sua nudez e, ao mesmo tempo, pela identificação. A partir da identificação, Deleuze e Guattari desenvolvem o conceito de Máquina Abstrata de Rostidade, que inscreve o sujeito na instituição, daí sugerirem o anonimato, o impessoal como forma de burlar esse reconhecimento.
} 
[o centro] Área fechada um circo preto: através do preto de dentro luzes estroboscópicas em ronda permanente. Pessoas dançam dentro música de discoteca. [a parte externa] Área com [ilegível] cavalo cavalgando na ronda.

Este vislumbre me veio hoje, dimanche e dedico a todos os meus amigos-amantes mortos (penso em CELSO RIBEIRO DOS SANTOS - morto há um mês, e a quem adorava - penso em PAULINHO, morto dias antes, na MANGUEIRA - penso em JERÔNIMO morto há anos em 69 quando eu estive em LONDRES)

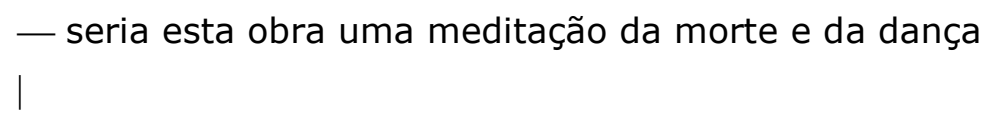

simultaneidade

tempo-dança

a morte ligada

a este tempo-dança como parte dele (OITICICA, 1979)

Os espectros que agitam a dança, as imagens que surgem dela, os fantasmas que a rodam imprimem o anacronismo próprio da dança, um tempo-dança, que corrobora com as afirmações de Giorgio Agamben e de Paul Valéry de que a essência da dança não é o movimento, mas o tempo. Por isso que a imagem, a imaginação ou a fantasia foram as propostas, os sopros de vida, de Hélio Oiticica para devolver potência a essas vidas, processo que é fundamental para podermos, enfim, formar o novo corpo da humanidade que se expandirá "sem limites para regiões do pensamento aberto em aberto" (OITICICA, 1973b).

O corpo dançante, um corpo nu e potente, alcança em seus movimentos uma conjugação do tempo que funde passado, presente e futuro, cria assim o instante, mas também um tempo aberto. É neste corpo que Paul Valéry vislumbra uma saída da lei, pois "libera uma energia que nenhum ato preciso pode absorver e esgotar em sua causa", ele é "uma potência superabundante" e não está submetido "a condições de economia" (VALÉRY, 2003, p. 34). O corpo dançante é um corpo sem vínculos, que não pode ser inscrito em nenhuma categoria, o que não pode ser classificado, qualificado e nomeado, é uma multiplicidade de nomes, uma abundância, um excesso. É, de acordo com JeanLuc Nancy (2006), um ser pluralmente singular e singularmente plural, uma simultaneidade. "Somos tudo ao mesmo tempo", diria Oiticica. 
"As imagens são móveis, rápidas, inapreensíveis - são o oposto do ícone, estático e característico das artes ditas plásticas - em verdade a dança, o ritmo, são o próprio ato plástico na sua crudeza essencial $\rightarrow$ está aí apontada a direção da descoberta da imanência" - anota Hélio Oiticica (1965) no seu texto sobre a dança. Como uma possibilidade de imanência, podemos dizer que os Parangolés sugerem o que Gilles Deleuze propôs ao definir a imanência como "uma vida...": não individualizada, mas singularizada. O artigo indefinido, como sabemos, marca para Deleuze a impessoalidade, o anonimato capaz de desterritorializar, ou seja, indica "um homem que não tem nenhum nome e que, apesar disso, não se confunde com nenhum outro" (DELEUZE, 2004), um nômade, um devir. O impessoal, portanto, "não é a indeterminação da pessoa sem antes ser a determinação do singular". Diz Hélio Oiticica: "o novo aqui é a possibilidade de valorização do indivíduo na coletividade", assinalando que pretendia com os Parangolés o anonimato: "quando eu levo as capas para a rua ela é anônima". E assim elas permanecem sobre os corpos da coletividade infame da favela: as capas não têm sujeito e não produzem um sujeito, ao contrário elas são devircoletivo e dessubjetivam na medida em que o corpo dançante aparece na gestualidade anônima de movimentos sem começo nem fim: "quando eu visto a capa ela não é só a medida do meu corpo mas também a de todos os corpos: eu sou o meio e o propulsor, mas nunca o fim: a alegria é leve e sem fins específicos: assim é o Parangolé" (OITICICA, 1973c). 


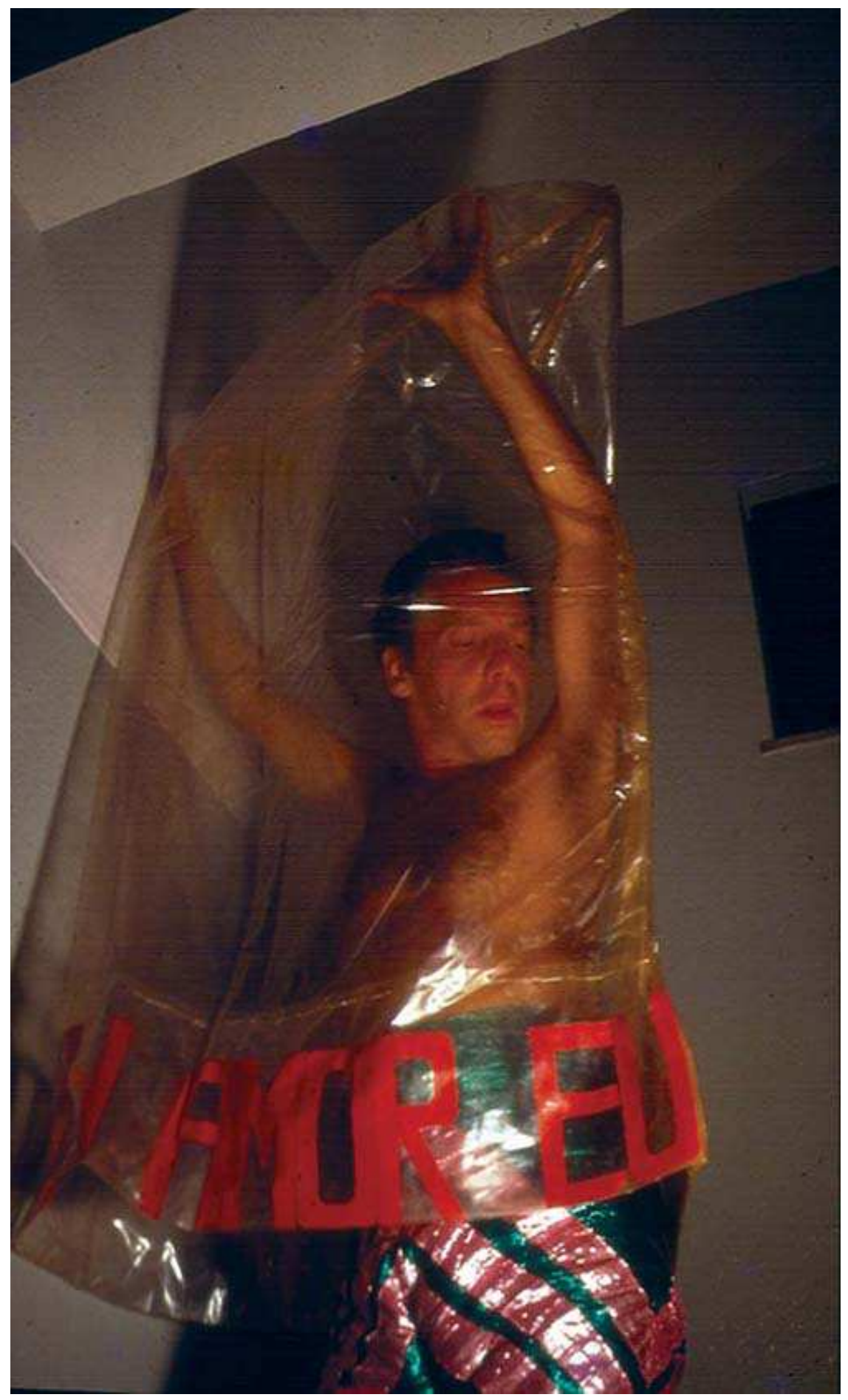

Figura 4: Hélio Oiticica vestindo o Parangolé "Teu amor eu guardo aqui"

Oiticica afirma que quer "criar uma linguagem, não importa por que meios ou como (...) não existe mais a preocupação de algo que evolua daqui para ali" (OITICICA, 1970a). Proposição que poderíamos reformular da seguinte maneira: Oiticica quer criar uma linguagem da voz. Exercer a prática-grito, ter o "direito ao grito" exigido por Macabéa, pressupõe um estado de emergência. Um grito 
interrompe a evolução, o discurso, a ordem do discurso. Ele faz falar o corpo. Hélio percebe que mais do que acumular, assimilar, o subterrâneo gasta. Percebe que o povo não precisa de técnicas de controle, mas da felicidade e que a vida em si, o simples fato de existir, já se concebe uma existência "política". ${ }^{11}$ Diz Oiticica:

Um pensamento político ou a participação nascem organicamente como a planta na planta do pé no mundo dos conceitos no do dia a dia: a luta toda se resume na ascensão de um pensamento não opressivo, de pensamentosações, para a absorção do que oprime: é o encosta-na-parede longe da encosta, na América do Sul, no Brasil que oprime - mar e guela [sic] - amerdicância tem que acabar no sul: de onde vem o mal? De dentro, de fora? Está em nós? - participar político é participar na vida: ser politicamente vivo é estar vivo: aspirar à felicidade: a não-utopia - (...) - pegar nas armas, tirar as amarras, limpar o lugar, o lazer, o prazer de se cuspir nas medalhas (...) - nos subterrâneos do mundo eu fico, por entre paredes, sob as gorgetas [sic], embaixo da vida: 3 dias e 3 noites: o limite do desvario [...]

A descoberta do mundo: extra-Brasil: é lógico que se ambicione a êle: estamos no hemisfério sul, ao sul e fora de jogada, na reserva do mundo - subterrânea é para mim a descoberta do que representa o sul do sul no mundo: só um tipo de comunicação (...) novo (...) (não-assimilatório), na prática (não-ritual): underground seriam a consciência e a eficácia da marginalidade das criações do que cria: a criação torna-se manifestação coletiva, não-ritualística: libertad! - a idéia de uma "integração" do artista no contexto social é falsa: ao artista caberia comandar as transformações que sobem: de dentro, de baixo, do sub ao subombear, puxar a liberdade, fazê-la crescer - [...]

para o mundo: ou no mundo. (OITICICA, 1969e)

Uma prática subterrânea reconhece que a política nasce da planta do pé. Reconhece que mais interessante do que olhar com os olhos seria, à maneira de Georges Bataille, olhar com o dedão do pé. A possibilidade de política e de pensamento está na criação, na tentativa de reinventar todos os dias, de criar constantemente a diferença, o múltiplo. Uma criação que, entretanto, não alimenta uma paixão do Real, a marca, segundo Alain Badiou, do século XX; que não tenta representá-lo, acolhê-lo, absorvê-lo, desenvolvê-lo, mas que deixa o outro viver ao seu modo de gozo. Essa criação subterrânea esfumaça as fronteiras entre arte e vida, abandona os mediadores. Privilegia o momento que se apresenta como eternidade e felicidade fugaz: "não me interessa a

\footnotetext{
${ }^{11} \mathrm{O}$ que é uma faca de dois gumes, porque inscrever o corpo na esfera pública é abrir espaço para a sua regulamentação, para a sua captura. Por isso não se pode perder de vista a advertência de Agamben (2000, p. 183): "todo pensamento que tem como objeto a vida compartilha deste objeto com o poder e deve confrontar-se com as suas estratégias".
} 
reprodução desse momento em palavras nem em obras, mas o momento ou a verificação futura dele por outrem". A prática ou política subterrânea trata, enfim, de um pensamento que advém do corpo: uma paixão que implica os fantasmas, que implica o outro, que não quer divisão. Agamben chama a atenção para a viv-ibilidade, procedimento de contemplação da potência que desprenderia a vida dos determinismos biológicos, sociais e econômicos:

Spinoza chama contemplação da potência, uma inoperosidade interna, por assim dizer, à mesma operação, uma praxis sui generis que consiste em tornar inoperante cada potência específica de agir e de fazer. A vida, que contempla a (própria) potência de agir, se rende inoperosa em todas as suas operações, vive somente a (sua) vivibilidade (...) A subjetividade, é isto que se abre como uma inoperosidade central em cada operação, como a viv-ibilidade de cada vida. Nessa inoperosidade, a vida que vivemos é somente a vida através da qual vivemos, apenas a nossa potência de agir e de viver, a nossa agibilidade e a nossa vivibilidade. A bios coincide aqui sem resíduos com a zoé. (AGAMBEN, 2007, p. 274)

Quarenta anos antes, Oiticica, da América Latina subterrânea, em pleno exercício da sua prática-grito, definiu a arte como a "formulação de uma possibilidade de vida" (OITICICA, 1970b). Na superfície dos corpos dançantes e desejantes dos Parangolés, nessa coletividade anônima e subterrânea, já se aventava uma coincidência sem resíduos entre bios e zoé. Ou parafraseando Walter Benjamin, um verdadeiro estado de emergência, que não é outra coisa senão, um estado de felicidade.

\section{Referências:}

AGAMBEN, Giorgio. Imanência absoluta. In: ALLIEZ, Eric (Org.). Gilles Deleuze: uma vida filosófica. São Paulo: Editora 34, 2000.

. Homo sacer I: o poder soberano e a vida nua. Trad. Henrique Burigo. Belo Horizonte: Editora da UFMG, 2002. . Nymphae. In: Aut aut. Milano, 2004.

. Il regno e la gloria: per una genealogia teologica dell'economia e del governo. (Homo sacer Vol. II, t. 2). Vicenza: Neri Pozza, 2007.

BADIOU, Alain. Pequeno manual de inestética. Trad. Marina Appenzeller. São Paulo: Estação Liberdade, 2002.

. O século. São Paulo: Idéias \& Letras, 2007. 
DELEUZE, Gilles. Imanência: uma vida... In: Terceira Margem. Rio de Janeiro: UFRJ, Ano IX, n.11, 2004.

FAVARETO, Celso. A invenção de Hélio Oiticica. São Paulo: Edusp, 2000.

HOLLANDA, Heloisa Buarque de. Impressões de Viagem: CPC, vanguarda e desbunde 1960/70. Rio de Janeiro: Aeroplano, 2004.

LISPECTOR, Clarice. A hora da estrela. Rio de Janeiro: Rocco, 1998.

. Mineirinho. Em: Para não esquecer. Rio de Janeiro: Rocco, 1999. Pp. 123-126.

NANCY, Jean-Luc. Ser singular plural. Trad. Antonio Tudela. Madrid: Arena, 2006.

VALÉRY, Paul. Degas Dança Desenho. Trad. Christina Murachco e Célia Euvaldo. São Paulo: Cosac \& Naify, 2003.

Textos de Hélio Oiticica consultados em arquivo:

O momento creativo [sic]. Maio/1961.

A dança na minha experiência. Nov/1965

Esquema Geral da Nova Objetividade. Dez/1966

A busca do supra-sensorial. Dez/ 1967

Poesia. Nov/1968

Subterrânia/Subterrânia 2. Setembro/1969. (1969a)

Experiência: capas 'construídas no corpo' (primeira prática Subterrânia [sic]). Nov/1969 (1969b)

As possibilidades do Crelazer. Maio/1969. (1969c)

Sem título. Fev/1969. (1969d)

Sexo Violência, 1969. (1969e)

Experiência Iondrina: subterrânea. Jan/1970. (1970a)

Meu trabalho é subterrâneo. Mar/1970. (1970b)

Mundo-Abrigo, Julho/1973. (1973a)

Sem título. Junho1973. (1973b)

Bodywise. Nov/1973. (1973c)

Sem título, 23/05/1979. (1979a)

Anotações e esboço para Parangolé-Área A Ronda da Morte. Maio/1979. (1979b)

\section{Title:}

Subterrânea: towards an effective state of emergency 


\section{Abstract:}

This paper attempts to deal with Hélio Oiticica's category "subterrânea", seeking to perceive the way it relates itself with the political purposes of the artist's works. Therefore, subterranean ("subterrânea") will be treated as a state of emergency, a state of latency, with which Oiticica tries to create a concept of "people", one where there would be no class divisions, no minorities or majorities, but a desiring collectivity, whose bodies seek happiness, that is, an effective state of emergency.

\section{Keywords:}

Subterrânea, Hélio Oiticica, Parangolé 